\title{
Distillery Raw Spent Wash as an Amendment for Reclamation of Sodic and Calcareous Sodic Soil
}

\author{
T. Bhagya Lakshmi ${ }^{1 *}$, C. A. Srinivasamurthy ${ }^{2}$, H. R. Savitha ${ }^{1}$, \\ D. H. Roopashree ${ }^{1}$ and S. Bhaskar ${ }^{3}$ \\ ${ }^{1} U A S$, GKVK, Bangalore-65, India \\ ${ }^{2}$ Directorate of Research, CAU, Imphal, India \\ ${ }^{3}$ Agronomy, Agro-Forestry and Climate Change, ICAR, New Delhi, India
}

*Corresponding author

\section{A B S T R A C T}

Keywords

Sodic soil,

Reclamation,

Gypsum

requirement,

Distillery raw

spentwash

Article Info

Accepted:

07 September 2019

Available Online:

10 October 2019
Sodic soils are characterized by adverse physical conditions with high sodium build up. These soils can be put to crop production only when they are reclaimed using calcium bearing chemical amendments. In this regard, attempts were made to study utilization of distillery spent wash to reclaim sodic soil and calcareous sodic soil. The raw distillery spent wash samples revealed that it was highly acidic $(\mathrm{pH} 4.11)$, with the electrical conductivity of $17.70 \mathrm{dS} \mathrm{m} \mathrm{m}^{-1}$. The concentration of nitrogen, phosphorus and potassium were $0.19,0.03$, and 0.88 per cent respectively and also has good amount of calcium and magnesium content of 2600 and $1700 \mathrm{mg} \mathrm{L}^{-1}$ respectively. In the pot experiment raw spent wash application @5.0 lakh liters ha ${ }^{-1}$ significantly reduced the $\mathrm{pH}$, exchangeable sodium and ESP of soil at 30 and 60 days after application and the reduction was marginal there after upto 120 days. Application of gypsum @100\% GR had similar effect in reducing the soil $\mathrm{pH}$ and ESP as that with raw spent wash application@ 2.5 lakh liters $\mathrm{ha}^{-1}$.

\section{Introduction}

Rapid rate of industrialization has accelerated soil and water pollution around the industrial units due to unscientific methods of discharge of waste materials on land or into water bodies. Since industrialization and pollution go together problem of disposal of industrial wastes assume paramount importance. In India molasses based distilleries are considered to be one of the most polluting agro-based industries due to generation of large amount of 
foul smelling, brown coloured waste water with very high BOD and COD. This waste water is also called as spent wash. Approximately 40 million $\mathrm{m} 3$ of distillery spent wash are discharged annually from 285 alcohol distilleries in India (Susheel Kumar $e t$ al., 2007). The raw spent wash is highly acidic in nature and possess high salt content and higher amounts of dissolved and suspended solids Though the spent wash has a high BOD and COD load, also has appreciable quantities of calcium along with plant nutrients and easily oxidisable organic matter. Thus it can be effectively used as a source of plant nutrients and as a soil amendment.

\section{Materials and Methods}

To study the effect of raw distillery spentwash and gypsum application on extent of reclamation of sodic and calcareous sodic soils, a green house experiment was conducted with two soils (viz., sodic and calcareous sodic) having $\mathrm{pH}>8.5$ and (ESP) (>15). Different quantities of raw spentwash (RSW) were applied in to pots containing soils on the basis of gypsum requirement of the soils.

For this study bulk quantity of sodic soil sample was collected from VC, Farm, Mandya and that of calcareous sodic soil was collected from farmer's field at Hadly village, Maddur Taluk, Mandya District, Karnataka. Both the soils were analyzed for mechanical composition, pH, EC, ESP and Organic Carbon content while the calcareous sodic soil was also analyzed for the lime content by following the standard procedures. The sodic soil was sandy clay loam in texture with $\mathrm{pH}$ 10.4 and ESP - 37.94 (per cent), electrical conductivity of $1.2 \mathrm{dS} \mathrm{m}^{-1}$ and the organic carbon content of 0.44 (per cent). The calcareous sodic soil was light black in colour with an alkaline reaction ( $\mathrm{pH}-9.5)$. The lime content was 8.5 per cent and the ESP was 28.65 per cent. The electrical conductivity and organic carbon contents were $0.8 \mathrm{dS} \mathrm{m} \mathrm{m}^{-1}$ and 0.36 per cent respectively. Hence, these two soils were selected to assess the extent of reclamation by using raw spentwash. The gypsum requirement of these two soils was estimated and based on G.R. values, the following treatments were fixed.

\section{Treatments}

$\mathrm{T}_{1}$ : Gypsum @ 50\% GR

T2: Gypsum @ 75\% GR

T3: Gypsum @ 100\% GR

$\mathrm{T}_{4}$ : Raw Spentwash @ 2.5 lakh liters ha ${ }^{-1}$

$\mathrm{T}_{5}$ : Raw Spentwash @ 5.0 lakh liters ha ${ }^{-1}$

$\mathrm{T}_{6}$ : Raw Spentwash @ 7.5 lakh liters ha ${ }^{-1}$

$\mathrm{T}_{7}$ : Raw Spentwash @ 10.0 lakh liters ha ${ }^{-1}$

\section{Replication: 3}

\section{Design}

\section{Completely Randomized Design}

The plastic pots (12 kg capacity) were cleaned and holes were made in the lower side of pots. Plastic tubes of diameter $1 \mathrm{~cm}$ and about $30 \mathrm{~cm}$ length were taken and holes were made and on one side of the tube and then the tube were covered with nylon cloth and placed in such a way that the holes were facing up in the pots. The tube was inserted into the hole and the sides of the holes were plastered with cement. Gravel was spread over the plastic tube to prevent entry of the soil particles into the tube and to collect clear leachate sample.

The pots were filled with $10 \mathrm{~kg}$ of processed and sieved sodic and calcareous sodic soil. Calculated quantities of gypsum/raw spent 
wash were applied to pots containing sodic/calcareous sodic soil as per the treatments. After 30 days of spentwash application, pots were leached with good quality water 3-4 times to leach out the sodium salts and two seedlings (30 days old) of rice variety IR-30864 were transplanted in each pot. Regular plant protection measures were taken up besides maintaining the submergence level with water throughout the crop period.

The leachate and soil samples were collected at 30,60, 90 and 120 days the soil sample were analyzed for $\mathrm{pH}, \mathrm{EC}$, Exch. $\mathrm{Na}, \mathrm{Ca} \mathrm{Mg}$ and ESP by following standard procedures.

The ESP of the soil was calculated using the formula $(\mathrm{ESP}=$ (Exchangeable sodium / Cation exchange capacity of soil) $\mathrm{X} 100$ ). The leachate samples were analyzed for $\mathrm{pH}, \mathrm{EC}$, Exch. $\mathrm{Na}, \mathrm{Ca}, \mathrm{Mg}, \mathrm{Na}, \mathrm{Cl}^{-}, \mathrm{CO}_{3}{ }^{2-}$ and $\mathrm{HCO}_{3}{ }^{-}$ by following standard procedures.

\section{Characterization of distillery spentwash}

Representative raw and primary treated spentwash samples collected from $\mathrm{M} / \mathrm{s}$ Chamundeshwari Distilleries Private Limited, K.M.Doddi, Maddur Taluk, Mandya district, were analyzed for different parameters. The $\mathrm{pH}$ of raw spentwash was 4.11 with the electrical conductivity of $17.70 \mathrm{dS} \mathrm{m}^{-1}$. The total suspended solids (TSS) and total dissolved solids (TDS) was 1.43 per cent and 5.20 per cent respectively. The biological oxygen demand (BOD) and chemical oxygen demand (COD) were $35320 \mathrm{mg} \mathrm{L}^{-1}$ and 94650 $\mathrm{mg} \mathrm{\textrm {L } ^ { - 1 }}$ respectively. The concentration of nitrogen, phosphorus and potassium were $0.19,0.03$, and 0.88 per cent respectively. Spent wash contained calcium, magnesium and sodium to an extent of $2600,1700,300.80$ $\mathrm{mg} \quad \mathrm{L}^{-1}$ respectively. The average concentration of iron, manganese, zinc and copper were 18.0, 5.8, 0.83 and $1.2 \mathrm{mg} \mathrm{L}^{-1}$ respectively. The sulphates and chloride concentration were $3316 \mathrm{mg} \mathrm{L}^{-1}$ and $8510 \mathrm{mg}$ $\mathrm{L}^{-1}$.

Effect of raw spentwash and gypsum on reclamation of sodic and calcareous sodic soil

The data pertaining to the effect of different levels of raw spentwash and gypsum application on pH, EC, Exch.Ca+Mg, Na, ESP and lime content of sodic and calcareous sodic soil are presented in Table 1 and 2.

\section{Soil pH}

Application of different quantities of raw spentwash and gypsum based on gypsum requirement of soil showed significant difference with respect to soil $\mathrm{pH}$ in both sodic and calcareous sodic soil. Reduction in soil $\mathrm{pH}$ was maximum in treatments receiving raw spentwash compared to gypsum application (Table 1).

Maximum reduction in soil $\mathrm{pH}$ of sodic soil was noticed in $\mathrm{T}_{6}$ (RSW@ 7.5 lakh liters ha ${ }^{-1}$ followed by $\mathrm{T}_{7}$ (RSW@10.0lakh liters ha ${ }^{-1}$ ) which was significantly superior over gypsum application. However, application of gypsum @ 100\% GR recorded $\mathrm{pH}$ of 10.06 which was on par with $\mathrm{T}_{4}$ (9.90) and $\mathrm{T}_{5}$ (9.79) which received 2.5 and 5.0 lakh liters of RSW respectively and were significantly superior over gypsum application @ 50\%GR (10.22). After 60 days after application, the decrease in $\mathrm{pH}$ was maximum in $\mathrm{T}_{5}(9.21)$ followed by $\mathrm{T}_{6}$ (9.39) and was significantly superior over $\mathrm{T}_{1}$ (9.93) and $\mathrm{T}_{2}(9.84)$.

Whereas in case of calcareous sodic soil significant reduction in $\mathrm{pH}$ was noticed in $\mathrm{T}_{5}$ (RSW@ 5.0 lakh liters $\mathrm{ha}^{-1}$ ) followed by $\mathrm{T}_{6}$ (RSW@7.5 lakh liters ha ${ }^{-1}$ ) and was significantly superior over gypsum application. However, application of gypsum 
@ 100\% GR recorded pH (8.46) which was significantly superior over gypsum application @ 50\%GR (8.92) and 75\% GR (8.62). After 60 days after application, the decrease in $\mathrm{pH}$ was maximum in $T_{5}$ (8.28) followed by $T_{6}$ (8.36) and was significantly superior over $\mathrm{T}_{1}$ (8.87) and $\mathrm{T}_{2}(8.58)$.

As the days after application progressed to 120 days, there was a slight reduction in soil $\mathrm{pH}$ when compared to 30 and 60 days in both the soils. However, at 120 days after application lowest soil $\mathrm{pH}$ was recorded in $\mathrm{T}_{5}$ (9.19) followed by $\mathrm{T}_{6}(9.35)$ in sodic and in calcareous sodic soil $8.24\left(\mathrm{~T}_{5}\right)$ and $8.33\left(\mathrm{~T}_{6}\right)$ respectively.

The reduction in soil $\mathrm{pH}$ was attributed to displacement of exchangeable $\mathrm{Na}$ by the calcium ion of gypsum and subsequent formation of sodium sulphate which get leached out of soil through drainage in the pots. Similar reduction in $\mathrm{pH}$ of sodic soil due to the application of gypsum was reported by Srinivasa (1995), Ramappa Jakanur (1998) and GuruPrasad (2005).

Decrease in soil $\mathrm{pH}$ in both the soils was attributed to acidic nature of raw spent wash ( $\mathrm{pH}$ 4.1) which might have solubilized the native calcium carbonate and released free calcium ions and other calcium bearing minerals to the soil. In addition the spent wash has calcium to an extent of $2600 \mathrm{mg} \mathrm{L}^{-1}$. There was marginal and minimum reduction in soil $\mathrm{pH}$ at 90 and 120 days after application compared to 60 days. The decrease in soil $\mathrm{pH}$ was more pronounced in Calcareous sodic soil compared to sodic soil. This was due to acidic nature of raw spent wash which might have solubilized the native free lime thus facilitating the release of $\mathrm{Ca}+\mathrm{Mg}$ in free ionic forms and these ions have replaced the $\mathrm{Na}^{+}$on the exchange complex. Also, the substantial quantity of sulfur present in raw spentwash, might have solubilised the $\mathrm{CaCO}_{3}$ thus decreasing the $\mathrm{pH}$ of soil. Results obtained in this study are in conformity with the findings of Mohammed Haroon and Subash Chandra Bose (2004) and Mahendra (2007).

\section{Electrical Conductivity}

The data pertaining to the effect of raw spentwash and gypsum application on electrical conductivity of sodic and calcareous sodic soil is presented in Table 1.

Application of raw spentwash at different quantities significantly increased the electrical conductivity of soil compared to gypsum treatments. Significantly highest soil electrical conductivity was recorded in $\mathrm{T}_{7}$ which received raw spentwash @ 10.0 lakh liters ha ${ }^{-1}$ $\left(6.41 \mathrm{dS} \mathrm{m}^{-1}\right)$ followed by $\mathrm{T}_{6}$ receiving 7.5 lakh liters $\mathrm{ha}^{-1}\left(5.77 \mathrm{dS} \mathrm{m}^{-1}\right)$ and was significantly higher over $\mathrm{T}_{5}\left(4.10 \mathrm{dS} \mathrm{\textrm {m } ^ { - 1 }}\right), \mathrm{T}_{4}$ $\left(4.10 \mathrm{dS} \mathrm{m}^{-1}\right)$ receiving 5.0 lakh liters ha ${ }^{-1,} 2.5$ lakh liters ha $^{-1}$. Application of gypsum slightly increased the soil EC but was not significant compared to raw spentwash application. However, highest EC $\left(2.43 \mathrm{dS} \mathrm{m}^{-1}\right)$ was recorded in $\mathrm{T}_{3}$ (gypsum at $100 \% \mathrm{GR}$ ) compared to initial value of $\left(1.81 \mathrm{dS} \mathrm{m}^{-1}\right)$.

Significant increase in EC of calcareous sodic soil was also noticed in $\mathrm{T}_{7}$ with RSW@ 10.0 lakh liters ha ${ }^{-1}\left(4.57 \mathrm{dS} \mathrm{m}^{-1}\right)$ followed by $\mathrm{T}_{6}$ with RSW@ 7.5 lakh liters $\mathrm{ha}^{-1}$ recorded significantly higher $\left(4.20 \mathrm{dS} \mathrm{m}^{-1}\right)$ value over gypsum application. However, application of gypsum slightly increased the soil EC but was not significant compared to raw spentwash application. However, gypsum @ 100\% GR $\left(\mathrm{T}_{3}\right)$ recorded a $\mathrm{EC}$ value of $1.15 \mathrm{dS} \mathrm{m}^{-}$ ${ }^{1}$ compared to the initial value of $0.64 \mathrm{dS} \mathrm{m}^{-1}$.

At 60 days after application also a similar trend was observed. Significantly highest electrical conductivity was recorded with $T_{7}$ $\left(5.23 \mathrm{dS} \mathrm{m}^{-1}\right)$ followed by $\mathrm{T}_{6}, \mathrm{~T}_{5}, \mathrm{~T}_{4}$ and was significantly superior over $\mathrm{T}_{3}\left(2.06 \mathrm{dS} \mathrm{m}^{-1}\right), \mathrm{T}_{2}$ 
(2.15 $\left.\mathrm{dS} \mathrm{m}^{-1}\right), \mathrm{T}_{1}\left(2.18 \mathrm{dS} \mathrm{m}^{-1}\right)$. In calcareous sodic soil also, highest electrical conductivity was recorded with $T_{7}$ which received raw spentwash @ 10.0 lakh liters ha ${ }^{-1}\left(4.28 \mathrm{dS} \mathrm{m}^{-1}\right)$ followed by $\mathrm{T}_{6}$ receiving raw spentwash @ 7.5 lakh liters ha ${ }^{-1}\left(3.77 \mathrm{dS} \mathrm{m}^{-1}\right), \mathrm{T}_{5}(2.84 \mathrm{dS}$ $\mathrm{m}^{-1}$ ) receiving raw spentwash @ 5.0 lakh liters $\mathrm{ha}^{-1}, \mathrm{~T}_{4}\left(1.86 \mathrm{dS} \mathrm{m}^{-1}\right)$ which received raw spentwash@2.5 lakh liters ha ${ }^{-1}$ and was significantly superior over $\mathrm{T}_{3}\left(1.12 \mathrm{dS} \mathrm{m}^{-1}\right) \mathrm{T}_{2}$ $\left(1.09 \mathrm{dS} \mathrm{m}^{-1}\right), \mathrm{T}_{1}\left(1.01 \mathrm{dS} \mathrm{m}^{-1}\right)$.

At 90 and 120 days after application, there was a slight reduction in soil EC compared to 30 and 60 days. However, at 120 days after application, highest soil EC was recorded in $\mathrm{T}_{7}\left(3.96 \mathrm{dS} \mathrm{m}^{-1}\right)$ followed by $\mathrm{T}_{6}\left(2.85 \mathrm{dS} \mathrm{m}^{-1}\right)$ and was found to be superior over application of gypsum @ 100\% GR that recorded (1.75 dS $\left.\mathrm{m}^{-1}\right)$. In calcareous sodic soil highest EC was noticed in $\mathrm{T}_{7}\left(3.58 \mathrm{dS} \mathrm{m}^{-1}\right)$ compared to gypsum @100\% GR (0.85 dS m $\left.{ }^{-1}\right)$.

Increased levels of raw spentwash application significantly increased electrical conductivity of both the soils and highest electrical conductivity value was noticed in treatment receiving 10.0 lakh liters $\mathrm{ha}^{-1}$. Application of gypsum also slightly increased the soil EC but was not significant compared to raw spentwash application. The increase in the soluble salt content in the gypsum amended pots might be attributed to the chemical reactions of gypsum in the soil rendering them to more soluble sulphate of sodium. The presence of more soluble salt resulted in higher conductivity values in gypsum treated pots.

There was no much variation between the two soils with respect to electrical conductivity values. However, there was a gradual reduction in soluble salt concentration with increase in the number of days after application of raw spentwash and gypsum which may be due to the leaching of soluble salts through drainage holes provided. However, at 120days after application highest soil $\mathrm{EC}$ was recorded in $\mathrm{T}_{7}$ receiving 10 lakh liters of ha ${ }^{-1}$ spentwash per hectare followed by $\mathrm{T}_{6}$ receiving 5.0 lakh liters $\mathrm{ha}^{-1}$ of spentwash per hectare and was found superior over application of gypsum @ 100\% GR.

Similarly in calcareous sodic soil, highest EC was noticed in $\mathrm{T}_{7}$ receiving 10 lakh liters ha ${ }^{-1}$ of spentwash per hectare as compared to gypsum @ 100\% GR. The decrease in conductivity values in each treatment over a period of time may be attributed to leaching of salts through drainage during reclamation. Chauhan and Tripathi (1983) reported that application of gypsum followed by leaching markedly reduced the electrical conductivity to normal levels in alkali soil. Similar results were also reported by Srinivasa (1995) and Guruprasad (2005).

Increased EC values in treatments involving spentwash may be due to the addition of soluble salts through raw spentwash which recorded electrical conductivity of $17.0 \mathrm{dS} \mathrm{m}$ 1. Significant increase in soluble salts concentration of soil due to high soluble salt content of raw spentwash was only temporary as drainage provided to these soils, leached the accumulated salts. Results obtained in this study are in close conformity with the findings of Anon. (2005). High amount of soluble salts present in spentwash on direct application to soil at higher levels creates the problem of salinity (Patil et al., 2000). Suma (2006) reported that one time application of distillery spentwash at $1000 \mathrm{~m}^{3} \mathrm{ha}^{-1}$ and $1500 \mathrm{~m}^{3} \mathrm{ha}^{-1}$ significantly increased the salt content of soil and was above the threshold level rendering these soils into saline soils.

\section{Exchangeable $\mathrm{Ca}+\mathrm{Mg}$}

The data pertaining to the effect of raw spentwash and gypsum application on 
Exch.Ca+Mg content of both sodic and calcareous sodic soil is presented in Table 1.

Application of raw spentwash at different quantities significantly increased the exchangeable $\mathrm{Ca}+\mathrm{Mg}$ of sodic soil compared to gypsum treatments. Significantly highest soil exchangeable $\mathrm{Ca}+\mathrm{Mg}$ was recorded in $\mathrm{T}_{7}$ (9.93 c mol $(\mathrm{p}+) \mathrm{kg}^{-1}$ ) receiving RSW@ 10.0 lakh liters $\mathrm{ha}^{-1}$ followed by $\mathrm{T}_{6}(9.72 \mathrm{c} \mathrm{mol}(\mathrm{p}+)$ $\left.\mathrm{kg}^{-1}\right)$ and $\mathrm{T}_{5}\left(9.65 \mathrm{c} \mathrm{mol}(\mathrm{p}+) \mathrm{kg}^{-1}\right)$ which received RSW@ 7.5 lakh liters $\mathrm{ha}^{-1}$ and RSW@5.0 lakh liters ha ${ }^{-1}$ respectively, but was significantly superior over $\mathrm{T}_{4}(8.08 \mathrm{c} \mathrm{mol}$ $(\mathrm{p}+) \mathrm{kg}^{-1}$ ) which received RSW@ 2.5 lakh liters $\mathrm{ha}^{-1}, \mathrm{~T}_{3}\left(7.30 \mathrm{c}\right.$ mol $\left.(\mathrm{p}+) \mathrm{kg}^{-1}\right)$ which received gypsum @ 100\% GR. However, significantly the lowest exchangeable $\mathrm{Ca}+\mathrm{Mg}$ was recorded in $\mathrm{T}_{1}\left(6.53 \mathrm{c}\right.$ mol $\left.(\mathrm{p}+) \mathrm{kg}^{-1}\right)$ which received gypsum @75\% GR.

Similarly, in calcareous sodic soil significantly highest soil exchangeable $\mathrm{Ca}+\mathrm{Mg}$ was recorded in $\mathrm{T}_{7}$ receiving RSW@ 10.0 lakh liters $\mathrm{ha}^{-1} .\left(25.0 \mathrm{c} \mathrm{mol}(\mathrm{p}+) \mathrm{kg}^{-1}\right)$ followed by $\mathrm{T}_{6}$ receiving RSW@ 7.5 lakh liters ha ${ }^{-1}$ (22.0 c mol $(\mathrm{p}+) \mathrm{kg}^{-1}$ ) but was significantly superior over the treatment which received RSW@ 5.0 lakh liters ha ${ }^{-1}\left(\mathrm{~T}_{5}\right)\left(19.83 \mathrm{c} \mathrm{mol}(\mathrm{p}+) \mathrm{kg}^{-1}\right), \mathrm{T}_{4}$ $\left(18.22 \mathrm{c} \mathrm{mol}(\mathrm{p}+) \mathrm{kg}^{-1}\right)$ and $\mathrm{T}_{3}(18.13 \mathrm{c} \mathrm{mol}$ $(\mathrm{p}+) \mathrm{kg}^{-1}$ ) However, significantly the lowest exchangeable $\mathrm{Ca}+\mathrm{Mg}$ was recorded in $\mathrm{T}_{1}$ $\left(16.22 \mathrm{c}\right.$ mol $\left.(\mathrm{p}+) \mathrm{kg}^{-1}\right)$ which received gypsum @50\% GR.

At 60 days after spentwash application, also a similar trend was followed in both the soils. Significantly highest $\left(9.83 \mathrm{c}\right.$ mol $\left.(\mathrm{p}+) \mathrm{kg}^{-1}\right)$ exchangeable $\mathrm{Ca}+\mathrm{Mg}$ was recorded with $\mathrm{T}_{7}$ which received RSW@ 10.0 lakh liters ha ${ }^{-1}$ followed by $\mathrm{T}_{6}\left(9.70\right.$ c mol $\left.(\mathrm{p}+) \quad \mathrm{kg}^{-1}\right)$ receiving RSW@ 7.5 lakh liters ha ${ }^{-1}$. The treatment $\mathrm{T}_{5}$ (RSW@5.0 lakh liters $\mathrm{ha}^{-1}$ ) recorded $\mathrm{Ca}+\mathrm{Mg}$ content of $9.59 \mathrm{c} \mathrm{mol}(\mathrm{p}+)$ $\mathrm{kg}^{-1}$ and was significantly superior over $\mathrm{T}_{2}$ $\left(6.73 \mathrm{c} \mathrm{mol}(\mathrm{p}+) \mathrm{kg}^{-1}\right), \mathrm{T}_{1}\left(6.40 \mathrm{c} \mathrm{mol}(\mathrm{p}+) \mathrm{kg}^{-1}\right)$ which received gypsum@ 75 and 50\% GR. In calcareous sodic soil significantly highest exchangeable $\mathrm{Ca}+\mathrm{Mg}$ was recorded with $\mathrm{T}_{7}$ (22.05 c mol $\left.(\mathrm{p}+) \mathrm{kg}^{-1}\right)$ followed by $\mathrm{T}_{6}(19.95$ c mol $\left.(\mathrm{p}+) \mathrm{kg}^{-1}\right) \cdot \mathrm{T}_{3}\left(17.85 \mathrm{c} \mathrm{mol}(\mathrm{p}+) \mathrm{kg}^{-1}\right)$ and was found to be on par with $\mathrm{T}_{4}(17.10 \mathrm{c}$ $\left.\mathrm{mol}(\mathrm{p}+) \mathrm{kg}^{-1}\right)$ and $\mathrm{T}_{5}\left(18.05 \mathrm{c} \mathrm{mol}(\mathrm{p}+) \mathrm{kg}^{-1}\right)$ significantly superior over $\mathrm{T}_{2}(16.70 \mathrm{c} \mathrm{mol}$ $\left.(\mathrm{p}+) \mathrm{kg}^{-1}\right), \mathrm{T}_{1}\left(15.83 \mathrm{c} \mathrm{mol}(\mathrm{p}+) \mathrm{kg}^{-1}\right)$. At 90 and 120days after application, there was a slight reduction in soil exchangeable $\mathrm{Ca}+\mathrm{Mg}$ compared to 30 and 60 days after application. However, at 120 days after application, highest exchangeable $\mathrm{Ca}+\mathrm{Mg}$ was recorded in $\mathrm{T}_{7}\left(9.57 \mathrm{c} \mathrm{mol}(\mathrm{p}+) \mathrm{kg}^{-1}\right)$ followed by $\mathrm{T}_{6}(9.48$ $\mathrm{c}$ mol $\left.(\mathrm{p}+) \mathrm{kg}^{-1}\right)$ and was found to be superior over application of gypsum @100\% GR which recorded $6.82 \mathrm{c} \mathrm{mol}(\mathrm{p}+) \mathrm{kg}^{-1}$.

Similarly, in calcareous sodic soil highest exchangeable $\mathrm{Ca}+\mathrm{Mg}$ was recorded in $\mathrm{T}_{7}$ $\left(23.10 \mathrm{c} \mathrm{mol}(\mathrm{p}+) \mathrm{kg}^{-1}\right)$ followed by $\mathrm{T}_{6}(19.62$ $\mathrm{c}$ mol $\left.(\mathrm{p}+) \mathrm{kg}^{-1}\right)$.

Increased application of raw spentwash at 5.0 lakh liters $\mathrm{ha}^{-1}$ increased exchangeable $\mathrm{Ca}+\mathrm{Mg}$ compared to gypsum treatments. This might be due to enhanced dissolution of free $\mathrm{CaCO}_{3}$ upon application of higher quantity of raw spentwash. During distillation of molasses, lime is added in distilleries to maintain the $\mathrm{pH}$, which ultimately accumulates in spentwash and becomes available in soils upon its application. Increased $\mathrm{Ca}+\mathrm{Mg}$ content in both the soil was due to the presence of $2600 \mathrm{mg} \mathrm{L}^{-}$ 1 of $\mathrm{Ca}$ and $1700 \mathrm{mg} \mathrm{L}^{-1}$ of $\mathrm{Mg}$ in raw spentwash that was added to the soils in different quantities which helped in better replacement of exchangeable sodium by $\mathrm{Ca}$ ions. Further, the acidic nature of raw spentwash ( $\mathrm{pH}$ 4.11) might have solubilized native free lime which released $\mathrm{Ca}+\mathrm{Mg}$ in free ionic forms which might have also contributed for increased $\mathrm{Ca}+\mathrm{Mg}$ on exchange sites with the replacement of exchangeable sodium. Similar observations were also reported by 
Santiago Mahimaraja and Nanthi Bolan (2000) and Baskar et al., (2003) that application of raw spentwash increased the $\mathrm{Ca}$ and $\mathrm{Mg}$ contents in red yellow medium textured latosol. After 60days of application, there was slight decrease in exchangeable $\mathrm{Ca}+\mathrm{Mg}$ contents in both the soils this may be due to leaching of $\mathrm{Ca}+\mathrm{Mg}$ salts from the soil along with sodium. Comparison between calcareous and other soil with respect to exchangeable $\mathrm{Ca}+\mathrm{Mg}$ contents indicated that calcareous sodic soil recorded higher $\mathrm{Ca}+\mathrm{Mg}$ than Sodic soil. The results obtained are in conformity with the findings of Mahendra (2007).

\section{Exchangeable Na}

The application of raw spentwash at different quantities significantly decreased the exchangeable sodium content of sodic and calcareous sodic soil compared to gypsum treatments (Table 2).

At 30 days after application, lowest exchangeable sodium content in sodic soil was recorded in $\mathrm{T}_{5}\left(5.43 \mathrm{c} \mathrm{mol}(\mathrm{p}+) \mathrm{kg}^{-1}\right)$ followed by $\mathrm{T}_{4}\left(5.59 \mathrm{c} \mathrm{mol}(\mathrm{p}+) \mathrm{kg}^{-1)}\right.$ and $\mathrm{T}_{3}(5.76 \mathrm{c} \mathrm{mol}$ $\left.(\mathrm{p}+) \mathrm{kg}^{-1}\right)$ respectively.

Significantly highest exchangeable sodium was recorded in $\mathrm{T}_{1}\left(6.71 \mathrm{c} \mathrm{mol}(\mathrm{p}+) \mathrm{kg}^{-1}\right), \mathrm{T}_{2}$ $\left(6.31 \mathrm{c} \mathrm{mol}(\mathrm{p}+) \mathrm{kg}^{-1}\right), \mathrm{T}_{6}\left(6.95 \mathrm{c} \mathrm{mol}(\mathrm{p}+) \mathrm{kg}^{-}\right.$ ${ }^{1}$ ) and $\mathrm{T}_{7}\left(7.10 \mathrm{c} \mathrm{mol}(\mathrm{p}+) \mathrm{kg}^{-1}\right)$. At 60,90 and 120 days after application there was slight reduction in soil exchangeable sodium compared to samples collected at 30 days. However, at 120 days after application, highest exchangeable sodium was recorded in $\mathrm{T}_{7}\left(6.97 \mathrm{c} \mathrm{mol}(\mathrm{p}+) \mathrm{kg}^{-1}\right)$ followed by $\mathrm{T}_{6}(6.73$ $\left.\mathrm{c} \mathrm{mol}(\mathrm{p}+) \mathrm{kg}^{-1}\right)$.

In calcareous sodic soil significantly lowest soil exchangeable sodium was recorded in $\mathrm{T}_{5}$ $\left(8.38 \mathrm{c} \mathrm{mol}(\mathrm{p}+) \mathrm{kg}^{-1}\right)$ followed by $\mathrm{T}_{4}(8.51 \mathrm{c}$ mol $\left.(p+) \mathrm{kg}^{-1}\right)$ and was significantly superior over $\mathrm{T}_{2}, \mathrm{~T}_{3}$ and was on par with $\mathrm{T}_{6}(9.12 \mathrm{c} \mathrm{mol}$ $\left(\mathrm{p}+\mathrm{kg}^{-1}\right)$ and $\mathrm{T}_{7}\left(9.28 \mathrm{c} \mathrm{mol}(\mathrm{p}+) \mathrm{kg}^{-1}\right)$. Significantly highest exchangeable sodium was recorded in $\mathrm{T}_{1}\left(9.78 \mathrm{c} \mathrm{mol}(\mathrm{p}+) \mathrm{kg}^{-1}\right)$ which received gypsum @ 50\% GR. At 60 days after application also similar trend was followed, significantly highest exchangeable sodium was recorded with $\mathrm{T}_{1}(8.79 \mathrm{c} \mathrm{mol}(\mathrm{p}+)$ $\left.\mathrm{kg}^{-1}\right)$ followed by $\mathrm{T}_{2}\left(8.59 \mathrm{c} \mathrm{mol}(\mathrm{p}+) \mathrm{kg}^{-1}\right)$. Gypsum@ $100 \% \quad$ GR $\quad\left(\mathrm{T}_{3}\right)$ recorded exchangeable sodium content of $(8.44 \mathrm{c}$ mol $(\mathrm{p}+) \mathrm{kg}^{-1}$ ) and was found on par with, $\mathrm{T}_{4}$ (RSW @ 2.5 lakh liter ha $\left.{ }^{-1}\right)\left(8.34 \mathrm{c} \mathrm{mol}(\mathrm{p}+) \mathrm{kg}^{-1)}, \mathrm{T}_{5}\right.$ (RSW@5.0 lakh liter ha ${ }^{-1}$ ) which recorded $8.28 \mathrm{c} \mathrm{mol}(\mathrm{p}+) \mathrm{kg}^{-1}$. Whereas, $\mathrm{T}_{7}$ and $\mathrm{T}_{6}$ treatments recorded exchangeable sodium content $9.21 \mathrm{c} \mathrm{mol}(\mathrm{p}+) \mathrm{kg}^{-1}$ and $9.05 \mathrm{c}$ mol $(\mathrm{p}+) \mathrm{kg}^{-1}$ respectively.

At 90 and 120 days after application, there was slight reduction in exchangeable sodium content of soil compared to 30 and 60 days. However, highest exchangeable sodium was recorded in $\mathrm{T}_{7}$ receiving RSW @ 10 lakh liter $\mathrm{ha}^{-1}\left(8.99 \mathrm{c}\right.$ mol $\left.(\mathrm{p}+) \mathrm{kg}^{-1}\right)$ followed by $\mathrm{T}_{6}$ receiving RSW@7.5 lakh liter $\mathrm{ha}^{-1}(8.68 \mathrm{c}$ $\mathrm{mol}\left(\mathrm{p}+\mathrm{kg}^{-1}\right)$.

The results are in accordance with the findings of Rachhpal Singh et al., (1980) who reported that application of concentrated form of spentwash helped in greater exchange of sodium by calcium and subsequent leaching with good quality water replaced the sodium from the exchange sites.

Similar observations were also reported by Mohammed Harron and Subash Chandra Bose (2004).With the increase in days after application of raw spentwash, there was gradual decrease in reduction of exchangeable sodium after 60days but there was sudden decrease in exchangeable sodium content at 30 and 60 days after application. Similar observations were also reported by Mahendra (2007). 


\section{Exchangeable sodium percentage}

Application of raw spentwash and gypsum at different quantities significantly decreased the exchangeable sodium percentage of soil compared to gypsum treatments (Table 2).

Significantly lowest soil exchangeable sodium percentage was recorded in $\mathrm{T}_{5}(27.30$ per cent $)$ which received RSW @ 5.0 lakh liters ha ${ }^{-1}$ and was significantly superior over $\mathrm{T}_{4}(28.40$ per cent), $\mathrm{T}_{6}\left(28.64\right.$ per cent) and $\mathrm{T}_{7}(29.50$ per cent) which received RSW @ 2.5 lakh liters $\mathrm{ha}^{-1,} 7.5$ lakh liters $\mathrm{ha}^{-1}$ and 10.0 lakh liters ha ${ }^{-1}$ respectively.

Among the gypsum applied treatments, maximum reduction in exchangeable sodium percentage was in $\mathrm{T}_{3}$ (28.97 per cent) followed by $\mathrm{T}_{2}$ and was superior over $\mathrm{T}_{1}$ (31.37 per cent).

Similarly, in calcareous sodic soil, lowest exchangeable sodium percentage was recorded in $T_{5}(19.67$ per cent) and was significantly superior over $\mathrm{T}_{4}$ (20.71 per cent), $\mathrm{T}_{6}(20.85$ per cent) and $\mathrm{T}_{7}(21.29$ per cent).

At 60 days after application also, a similar trend was followed. Significantly highest exchangeable sodium percentage was recorded with $\mathrm{T}_{1}$ (29.50 per cent) followed by $\mathrm{T}_{2}(28.82$ per cent) and was on par with $\mathrm{T}_{7}$ and $\mathrm{T}_{6}$ which recorded (26.85 per cent) and 28.38 respectively.

The lowest exchangeable sodium percentage of (24.69 per cent) was recorded in $\mathrm{T}_{5}$ (RSW @ 5.0 lakh liter $\mathrm{ha}^{-1}$ ) and was found on par with $\mathrm{T}_{4}$ (RSW @ 5.0 lakh liter ha ${ }^{-1}$ ) (25.86 per cent).

Similarly in calcareous sodic soil, lowest exchangeable sodium percentage of (18.46 per cent) was recorded in $\mathrm{T}_{5}$ (RSW @ 5.0 lakh liter ha ${ }^{-1}$ ) and was found on par with, $\mathrm{T}_{4}(\mathrm{RSW}$
@ 5.0 lakh liter $\left.\mathrm{ha}^{-1}\right)$ (19.09 per cent) and found significantly superior over $\mathrm{T}_{6}(19.79 \mathrm{per}$ cent), $\mathrm{T}_{7}\left(20.92\right.$ per cent) and $\mathrm{T}_{3}(19.37$ per cent).

At 90 and 120 days after application, there was slight reduction in exchangeable sodium percentage of soil compared to 30 and 60 days. However, in sodic soil lowest exchangeable sodium percentage of 20.38 per cent was recorded in $T_{5}$ which received raw spentwash@5.0 lakh liters ha ${ }^{-1}$. In calcareous sodic soil also a similar trend of results was observed.

RSW @ (5.0 lakh liters ha $\left.^{-1}\right)$ treatment considered optimum for practical purpose for reducing the ESP to a desired level under field conditions.

The results are in accordance with the findings of Rachhpal Singh et al., (1980), Rajakunnu et al., (1996), Valliappan (1998) and Mohammed Haroon and Subash Chandra Bose (2004),. With the increase in days after application of raw spentwash there was gradual reduction in ESP.

\section{Lime content of calcareous sodic soil}

Application of different quantities of raw spentwash significantly decreased the lime content of soil compared to gypsum treatments (Table 2).

Significantly lowest lime content was recorded in $\mathrm{T}_{7}$ with RSW @ 10.0 lakh liter ha ${ }^{1}$ (5.36 per cent) followed by $\mathrm{T}_{6}(5.40$ per cent) receiving RSW @ 7.5 lakh liter ha ${ }^{-1}, \mathrm{~T}_{5}$ (5.96 per cent) RSW @ 5.0 lakh liter ha ${ }^{-1}$ and was significantly superior over gypsum applied treatments which recorded 8.27 per cent followed by $T_{2}, T_{1}$ which were not significant. At 60 days after application, also a similar trend was followed. Significantly lowest lime content (5.24 per cent) was 
recorded in $\mathrm{T}_{7}$ (RSW @ 10.0 lakh liter $\mathrm{ha}^{-1}$ ) followed by $\mathrm{T}_{6}$ (RSW@ 9.5 lakh liter $\mathrm{ha}^{-1}$ ) (5.35 per cent) and $\mathrm{T}_{5}(5.65$ per cent $)$.

At 90 and 120 days after application, there was a slight reduction in lime content of soil compared to 30 and 60days. However, the highest (8.22 per cent) lime content was recorded in $\mathrm{T}_{1}$ and lowest in $\mathrm{T}_{7}$ (5.06 per cent).

Application of raw spentwash at different quantities significantly decreased the $\mathrm{CaCO}_{3}$ content of soil.

The lowest $\mathrm{CaCO}_{3}$ content for both the soils was recorded in treatment $T_{7}$ which received 10.0 lakh liters $\mathrm{ha}^{-1}$ followed by $\mathrm{T}_{6}$ (7.5 lakh liters $\mathrm{ha}^{-1}$ ).

The decrease in free lime content of soil with increased levels of raw spentwash might be due to greater solublization of alkaline earth carbonates brought about by acidic nature of raw spentwash.

The results are in conformity with the findings of Anonymous (2002) for calcareous soils of Somayannur series in Tamil Nadu and Mahendra (2007).

\section{Chemical composition of leachate}

The data pertaining to chemical composition of leachate collected after 30, 60 and 90 days of raw spent wash application in both sodic \& calcareous sodic is presented in Tables 3 and 4 , respectively.

Increasing the quantity of RSW application increased the soluble salts content in leachate compared to gypsum application in both sodic and calcareous sodic soil.In general, $\mathrm{pH}, \mathrm{EC}$, $\mathrm{Ca}+\mathrm{Mg}, \mathrm{Na}^{+}, \mathrm{HCO}_{3}{ }^{-}, \mathrm{Cl}^{-}, \mathrm{SO}_{4}{ }^{2-}$ increased with increase in the rate of spentwash application. Among the cations, the quantity of sodium leached was more compared to calcium and magnesium and among the anions $\mathrm{HCO}_{3}{ }^{-}$was leached more compared to chlorides and sulphates.

With increase in days after raw spentwash application soluble salt concentration decreased over period.

Increase in soluble salt concentration was significantly superior over gypsum treatments. Significantly higher values were recorded for each parameter at 30days after application in raw spentwash received pots and thereafter and over a period of time (120days) significant reduction was noticed.

At 30 days after application, significantly highest $\mathrm{pH}, \mathrm{EC}, \mathrm{Ca}^{2+}, \mathrm{Mg}^{2+} \mathrm{HCO}_{3}^{-}, \mathrm{Cl}^{-}$and $\mathrm{SO}_{4}{ }^{2-}, \mathrm{Na}^{+}$, of $9.86,19.77 \mathrm{dS} \mathrm{m}{ }^{-1}, 23.91 \mathrm{meq}$ $\mathrm{L}^{-1}, 20.33$ meq L ${ }^{-1}, 13.32$ meq L ${ }^{-1}, 6.06$ meq L $1,7.18 \mathrm{meq}^{-1}$ respectively were recorded in $\mathrm{T}_{7}$ which received raw spentwash @ 10.0 lakh liters ha ${ }^{-1}$ followed by $\mathrm{T}_{6} \mathrm{~T}_{5}$ and $\mathrm{T}_{4}$ compared to gypsum application. After 120days after application, the values got reduced to 9.13, $8.0 \mathrm{dS} \mathrm{m} \mathrm{m}^{-1}, 16.57 \mathrm{meq} \mathrm{L} \mathrm{L}^{-1}, 12.48 \mathrm{meq} \mathrm{L}^{-1}$, 11.79 meq $\mathrm{L}^{-1}, 4.63 \mathrm{meq} \mathrm{L}^{-1}, 6.41 \mathrm{meq} \mathrm{L}^{-}$ ${ }^{1}$ respectively.

The leachate collected at different intervals in calcareous sodic soil also followed similar trend. At 30days after application significantly highest $\mathrm{pH}, \mathrm{EC}, \mathrm{Ca}^{2+}, \mathrm{Mg}^{2+} \mathrm{HCO}_{3}^{-}, \mathrm{Cl}^{-}$and $\mathrm{SO}_{4}{ }^{2-,} \mathrm{Na}^{+}$, of 9.50, 7.10 dS m${ }^{-1}, 30.5 \mathrm{meq} \mathrm{L}^{-1}$, 12.5 meq $\mathrm{L}^{-1}, 14.8 \mathrm{meq} \mathrm{L}^{-1}, 6.78 \mathrm{meq} \mathrm{L}^{-1}, 8.12$ meq $\mathrm{L}^{-1}$ respectively were recorded in $\mathrm{T}_{7}$ which received raw spent wash@10.0 lakh liters ha ${ }^{-1}$ followed by $\mathrm{T}_{6}$ (RSW @ 7.5 lakh liters ha $\left.{ }^{-1}\right), \mathrm{T}_{5}\left(\mathrm{RSW} @ 5.0\right.$ lakh liters ha $\left.{ }^{-1}\right)$ and $\mathrm{T}_{4}$ (RSW@2.5 lakh liters ha ${ }^{-1}$ ) compared to gypsum application.

After 120days after application, the values got reduced to $9.08,6.14 \mathrm{dS} \mathrm{m}^{-1}, 22.25 \mathrm{meq} \mathrm{L}^{-1}$, $5.94 \mathrm{meq} \mathrm{L} \mathrm{L}^{-1}, 11.64 \mathrm{meq} \mathrm{L}{ }^{-1}, 6.18 \mathrm{meq} \mathrm{L}^{-1}$, $7.28 \mathrm{meq} \mathrm{L}^{-1}$ respectively. 
Table.1 Effect of raw spentwash and gypsum application on $\mathrm{pH}, \mathrm{EC}$ and exchangeable Calcium+Magnesium content of sodic and calcareous sodic soil

\begin{tabular}{|c|c|c|c|c|c|c|c|c|c|c|c|c|c|c|c|c|c|c|c|c|c|c|c|c|}
\hline \multirow[t]{3}{*}{ Treatments } & \multicolumn{8}{|c|}{$\mathrm{pH}(1: 2)$} & \multicolumn{8}{|c|}{$\mathrm{EC}\left(\mathrm{dS} \mathrm{m} \mathrm{m}^{-1}\right)$} & \multicolumn{8}{|c|}{$\operatorname{Exch} . \mathrm{Ca}+\mathrm{Mg}\left(\mathrm{c} \operatorname{mol}\left(\mathrm{p}^{+}\right) \mathrm{kg}^{-1}\right)$} \\
\hline & \multicolumn{4}{|c|}{ Sodic soil } & \multicolumn{4}{|c|}{ Calcareous sodic soil } & \multicolumn{4}{|c|}{ Sodic soil } & \multicolumn{4}{|c|}{ Calcareous sodic soil } & \multicolumn{4}{|c|}{ Sodic soil } & \multicolumn{4}{|c|}{ Calcareous sodic soil } \\
\hline & $\begin{array}{c}\text { 30 } \\
\text { days }\end{array}$ & $\begin{array}{c}60 \\
\text { days }\end{array}$ & $\begin{array}{c}90 \\
\text { days }\end{array}$ & $\begin{array}{c}120 \\
\text { days }\end{array}$ & $\begin{array}{c}30 \\
\text { days }\end{array}$ & $\begin{array}{c}60 \\
\text { days }\end{array}$ & $\begin{array}{c}90 \\
\text { days }\end{array}$ & $\begin{array}{c}120 \\
\text { days }\end{array}$ & $\begin{array}{c}30 \\
\text { days }\end{array}$ & $\begin{array}{c}60 \\
\text { days }\end{array}$ & $\begin{array}{c}90 \\
\text { days }\end{array}$ & $\begin{array}{c}120 \\
\text { days }\end{array}$ & $\begin{array}{c}30 \\
\text { days }\end{array}$ & $\begin{array}{c}60 \\
\text { days }\end{array}$ & $\begin{array}{c}90 \\
\text { days }\end{array}$ & $\begin{array}{c}120 \\
\text { days }\end{array}$ & $\begin{array}{c}30 \\
\text { days }\end{array}$ & $\begin{array}{c}60 \\
\text { days }\end{array}$ & $\begin{array}{c}90 \\
\text { days }\end{array}$ & $\begin{array}{c}120 \\
\text { days }\end{array}$ & $\begin{array}{c}30 \\
\text { days }\end{array}$ & $\begin{array}{c}60 \\
\text { days }\end{array}$ & $\begin{array}{c}90 \\
\text { days }\end{array}$ & $\begin{array}{c}120 \\
\text { days }\end{array}$ \\
\hline $\mathrm{T}_{1}$ & 10.22 & 9.93 & 9.84 & 9.83 & 8.92 & 8.87 & 8.84 & 8.83 & 2.32 & 2.18 & 1.88 & 1.82 & 1.12 & 1.01 & 0.91 & 0.85 & 7.24 & 6.53 & 6.40 & 6.39 & 16.22 & 15.83 & 15.62 & 15.41 \\
\hline $\mathrm{T}_{2}$ & 10.05 & 9.84 & 9.77 & 9.75 & 8.62 & 8.58 & 8.53 & 8.52 & 2.37 & 2.15 & 1.95 & 1.76 & 1.14 & 1.09 & 1.06 & 1.08 & 7.33 & 6.88 & 6.73 & 6.54 & 17.19 & 16.70 & 16.30 & 16.12 \\
\hline $\mathrm{T}_{3}$ & 10.06 & 9.64 & 9.55 & 9.52 & 8.46 & 8.48 & 8.45 & 8.44 & 2.43 & 2.06 & 1.86 & 1.75 & 1.15 & 1.12 & 1.04 & 1.05 & 7.82 & 7.30 & 7.29 & 7.24 & 18.13 & 17.85 & 16.58 & 16.30 \\
\hline $\mathrm{T}_{4}$ & 9.90 & 9.68 & 9.54 & 9.50 & 8.57 & 8.45 & 8.43 & 8.41 & 3.86 & 2.59 & 2.23 & 1.83 & 1.98 & 1.86 & 1.48 & 1.35 & 8.66 & 8.08 & 8.03 & 7.85 & 18.22 & 17.10 & 16.95 & 16.41 \\
\hline $\mathrm{T}_{5}$ & 9.79 & 9.21 & 9.18 & 9.19 & 8.33 & 8.28 & 8.25 & 8.24 & 4.10 & 3.94 & 2.72 & 2.12 & 3.15 & 2.84 & 2.52 & 1.90 & 9.65 & 8.59 & 8.46 & 8.22 & 19.83 & 18.05 & 17.52 & 17.18 \\
\hline $\mathrm{T}_{6}$ & 9.64 & 9.39 & 9.35 & 9.32 & 8.38 & 8.36 & 8.34 & 8.33 & 5.77 & 4.17 & 3.96 & 2.45 & 4.20 & 3.77 & 3.41 & 2.72 & 9.72 & 8.70 & 8.53 & 8.33 & 22.0 & 19.95 & 19.88 & 19.62 \\
\hline $\mathrm{T}_{7}$ & 9.68 & 9.51 & 9.53 & 9.51 & 8.53 & 8.44 & 8.42 & 8.42 & 6.41 & 5.23 & 4.18 & 3.96 & 4.57 & 4.28 & 3.93 & 3.58 & 9.83 & 8.93 & 8.65 & 8.37 & 25.0 & 22.05 & 23.93 & 23.10 \\
\hline SEm \pm & 0.056 & 0.18 & 0.11 & 0.07 & 0.15 & 0.07 & 0.22 & 0.22 & 0.49 & 0.228 & 0.12 & 0.09 & 0.31 & 0.21 & 0.22 & 0.22 & 0.077 & 0.81 & 0.48 & 0.69 & 0.85 & 0.45 & 0.44 & 0.44 \\
\hline$C D p=0.05)$ & 0.232 & 0.55 & 0.33 & 0.23 & 0.64 & 0.21 & 0.67 & 0.66 & 1.47 & 0.67 & 0.37 & 0.28 & 0.93 & 0.65 & 0.65 & 0.65 & 0.23 & 2.46 & 1.47 & 2.08 & 2.57 & 1.35 & 1.31 & 1.33 \\
\hline & $\begin{array}{l}\mathrm{T}_{1} \text { Gypsu } \\
\mathrm{T}_{2} \text { : Gyp } \\
\mathrm{T}_{3} \text { : Gyps } \\
\mathrm{T}_{4}: \text { Spen } \\
\mathrm{T}_{5} \text { : Spen } \\
\mathrm{T}_{6} \text { : Spen } \\
\mathrm{T}_{7} \text { : Spen }\end{array}$ & $\begin{array}{l}\text { um @ } \\
\text { sum @ } \\
\text { sum @ } \\
\text { ntwash } \\
\text { ntwash } \\
\text { ntwash } \\
\text { ntwash }\end{array}$ & $\begin{array}{l}50 \% \mathrm{GK} \\
75 \% \mathrm{C} \\
100 \% \\
@ 2.51 \\
@ 5.0 \\
@ 7.5 \\
@ 10.0\end{array}$ & $\begin{array}{l}\text { R: } \\
\text { GR } \\
\text { GR } \\
\text { lakh lite } \\
\text { lakh lite } \\
\text { lakh lite }\end{array}$ & $\begin{array}{l}\text { ers ha }^{-1} \\
\text { ers ha }^{-1} \\
\text { ers ha }^{-1}\end{array}$ & & & & & & & & & & & & & & & & & & & \\
\hline
\end{tabular}


Table.2 Effect of raw spentwash and gypsum application on exchangeable sodium, exchangeable percentage \& lime content of sodic and calcareous sodic soil

\begin{tabular}{|c|c|c|c|c|c|c|c|c|c|c|c|c|c|c|c|c|c|c|c|c|}
\hline \multirow[t]{3}{*}{ Treatments } & \multicolumn{8}{|c|}{$\begin{array}{c}\text { Exch. Na } \\
\left(\text { c mol }\left(p^{+}\right) \mathrm{kg}^{-1}\right)\end{array}$} & \multicolumn{8}{|c|}{$\begin{array}{c}\text { ESP } \\
\text { (per cent ) }\end{array}$} & \multirow{2}{*}{\multicolumn{4}{|c|}{$\begin{array}{c}\begin{array}{c}\text { Lime content } \\
\text { (per cent })\end{array} \\
\text { Calcareous sodic soil }\end{array}$}} \\
\hline & \multicolumn{4}{|c|}{ Sodic soil } & \multicolumn{4}{|c|}{ Calcareous sodic soil } & \multicolumn{4}{|c|}{ Sodic soil } & \multicolumn{4}{|c|}{ Calcareous sodic soil } & & & & \\
\hline & $\begin{array}{c}30 \\
\text { days }\end{array}$ & 60 days & 90 days & $\begin{array}{c}120 \\
\text { days }\end{array}$ & 30 days & $\begin{array}{c}60 \\
\text { days }\end{array}$ & $\begin{array}{c}90 \\
\text { days }\end{array}$ & 120 days & $\begin{array}{c}30 \\
\text { days }\end{array}$ & $\begin{array}{c}60 \\
\text { days }\end{array}$ & $\begin{array}{c}90 \\
\text { days }\end{array}$ & $\begin{array}{c}120 \\
\text { days }\end{array}$ & $\begin{array}{c}30 \\
\text { days }\end{array}$ & $\begin{array}{c}60 \\
\text { days }\end{array}$ & $\begin{array}{c}90 \\
\text { days }\end{array}$ & $\begin{array}{c}120 \\
\text { days }\end{array}$ & $\begin{array}{c}30 \\
\text { days }\end{array}$ & $\begin{array}{c}60 \\
\text { days }\end{array}$ & $\begin{array}{c}90 \\
\text { days }\end{array}$ & $\begin{array}{c}120 \\
\text { days }\end{array}$ \\
\hline $\mathrm{T}_{1}$ & 9.78 & 8.79 & 8.74 & 8.79 & 6.71 & 6.65 & 6.42 & 6.40 & 31.37 & 29.50 & 26.51 & 25.76 & 24.20 & 23.87 & 22.52 & 22.47 & 8.23 & 8.20 & 8.21 & 8.22 \\
\hline $\mathrm{T}_{2}$ & 9.63 & 8.59 & 8.51 & 8.55 & 6.31 & 6.25 & 6.23 & 6.22 & 29.75 & 28.82 & 24.87 & 24.03 & 23.71 & 21.18 & 20.71 & 20.63 & 8.26 & 8.22 & 8.23 & 8.24 \\
\hline $\mathrm{T}_{3}$ & 9.48 & 8.44 & 8.34 & 8.13 & 5.76 & 5.59 & 5.52 & 5.47 & 28.97 & 26.51 & 23.25 & 23.08 & 21.23 & 19.37 & 19.29 & 19.07 & 8.27 & 8.26 & 8.22 & 8.25 \\
\hline $\mathrm{T}_{4}$ & 8.51 & 8.34 & 8.33 & 8.18 & 5.59 & 5.42 & 5.39 & 5.26 & 28.40 & 25.86 & 23.67 & 23.11 & 20.71 & 19.09 & 18.91 & 18.98 & 6.36 & 6.27 & 6.17 & 6.08 \\
\hline $\mathrm{T}_{5}$ & 8.38 & 8.28 & 8.00 & 7.95 & 5.43 & 5.26 & 5.18 & 5.11 & 27.30 & 24.69 & 22.78 & 20.38 & 19.67 & 18.46 & 18.35 & 18.29 & 5.96 & 5.65 & 5.50 & 5.39 \\
\hline $\mathrm{T}_{6}$ & 9.12 & 9.05 & 8.74 & 8.99 & 6.95 & 6.83 & 6.78 & 6.73 & 28.64 & 26.85 & 25.39 & 24.83 & 20.85 & 19.79 & 19.52 & 19.46 & 5.40 & 5.35 & 5.29 & 5.25 \\
\hline $\mathrm{T}_{7}$ & 9.28 & 9.21 & 8.92 & 8.68 & 7.10 & 7.08 & 7.02 & 6.97 & 29.50 & 28.38 & 27.63 & 27.38 & 21.29 & 20.92 & 20.84 & 20.66 & 5.36 & 5.24 & 5.12 & 5.06 \\
\hline SEm \pm & 0.47 & 0.13 & 0.14 & 0.12 & 0.22 & 0.22 & 0.49 & 0.44 & 0.62 & 0.88 & 1.38 & 0.93 & 0.66 & 0.79 & 0.66 & 0.44 & 0.45 & 0.73 & 0.91 & 1.09 \\
\hline $\begin{array}{c}\text { CD } \\
(p=0.05)\end{array}$ & 1.00 & 0.28 & 0.30 & 0.26 & 0.66 & 0.66 & 1.47 & 1.32 & 1.33 & 1.88 & 2.95 & 1.98 & 1.99 & 2.38 & 1.98 & 1.33 & 1.36 & 2.19 & 2.74 & 3.30 \\
\hline & $\begin{array}{l}{ }_{1} \text { Gypsu } \\
{ }_{2}: \text { Gyps } \\
{ }_{3}: \text { Gyps } \\
{ }_{4}: \text { Spen } \\
{ }_{5}: \text { Spen } \\
6 \text { : Spen } \\
{ }_{7}: \text { Spen }\end{array}$ & $\begin{array}{l}\mathrm{n} @ 50 \% \\
\mathrm{um} @ 75 \% \\
\mathrm{um} @ 100 \% \\
\text { wash @ } 2.5 \\
\text { wash @ } 5.0 \\
\text { wash @ } 7.5 \\
\text { wash @ } 10 .\end{array}$ & $\begin{array}{l}\text { GR: } \\
\text { GR } \\
\% \text { GR } \\
5 \text { lakh liter } \\
0 \text { lakh liter } \\
5 \text { lakh liter } \\
0.0 \text { lakh lite }\end{array}$ & $\begin{array}{l}\mathrm{ha}^{-1} \\
\mathrm{ha}^{-1} \\
\mathrm{ha}^{-1} \\
\mathrm{rs} \mathrm{ha}^{-1}\end{array}$ & & & & & & & & & & & & & & & & \\
\hline
\end{tabular}


Table.3 Effect of raw spentwash and gypsum application on $\mathrm{pH}, \mathrm{EC}, \mathrm{Ca}+\mathrm{Mg}$, $\mathrm{Na}$, chlorides and bicarbonates content of leachate collected from sodic and calcareous sodic soil.

\begin{tabular}{|c|c|c|c|c|c|c|c|c|c|c|c|c|c|c|c|c|c|c|c|c|c|c|c|c|}
\hline \multirow[t]{3}{*}{ Treatments } & \multicolumn{8}{|c|}{ pH } & \multicolumn{8}{|c|}{$E C\left(d S m^{-1}\right)$} & \multicolumn{8}{|c|}{ Exch.Ca+Mg $\left(\operatorname{meq} L^{-1}\right)$} \\
\hline & \multicolumn{4}{|c|}{ Sodic } & \multicolumn{4}{|c|}{ Calcareous sodic } & \multicolumn{4}{|c|}{ Sodic } & \multicolumn{4}{|c|}{ Calcareous sodic } & \multicolumn{4}{|c|}{ Sodic } & \multicolumn{4}{|c|}{ Calcareous Sodic } \\
\hline & $\begin{array}{c}30 \\
\text { days }\end{array}$ & $\begin{array}{c}60 \\
\text { days }\end{array}$ & $\begin{array}{c}90 \\
\text { days }\end{array}$ & $\begin{array}{c}120 \\
\text { days }\end{array}$ & $\begin{array}{c}30 \\
\text { days }\end{array}$ & $\begin{array}{c}60 \\
\text { days }\end{array}$ & $\begin{array}{c}90 \\
\text { days }\end{array}$ & $\begin{array}{c}120 \\
\text { days }\end{array}$ & $\begin{array}{c}30 \\
\text { days }\end{array}$ & $\begin{array}{c}60 \\
\text { days }\end{array}$ & $\begin{array}{c}90 \\
\text { days }\end{array}$ & $\begin{array}{c}120 \\
\text { days }\end{array}$ & $\begin{array}{c}30 \\
\text { days }\end{array}$ & $\begin{array}{c}60 \\
\text { days }\end{array}$ & $\begin{array}{c}90 \\
\text { days }\end{array}$ & $\begin{array}{c}120 \\
\text { days }\end{array}$ & $\begin{array}{c}30 \\
\text { days }\end{array}$ & $\begin{array}{c}60 \\
\text { days }\end{array}$ & $\begin{array}{c}90 \\
\text { days }\end{array}$ & $\begin{array}{c}120 \\
\text { days }\end{array}$ & $\begin{array}{c}30 \\
\text { days }\end{array}$ & $\begin{array}{c}60 \\
\text { days }\end{array}$ & $\begin{array}{c}90 \\
\text { days }\end{array}$ & $\begin{array}{c}120 \\
\text { days }\end{array}$ \\
\hline $\mathrm{T}_{1}$ & 8.45 & 8.31 & 8.19 & 8.13 & 7.41 & 7.38 & 7.32 & 7.28 & 1.62 & 1.43 & 1.10 & 0.89 & 0.83 & 0.82 & 0.83 & 0.83 & 9.64 & 8.97 & 8.5 & 8.64 & 14.5 & 13.45 & 12.5 & 10.5 \\
\hline $\mathrm{T}_{3}$ & 8.86 & 8.50 & 8.36 & 8.19 & 7.58 & 7.57 & 7.41 & 7.36 & 2.14 & 1.96 & 1.71 & 1.07 & 0.91 & 0.89 & 0.86 & 0.84 & 13.45 & 10.96 & 10.5 & 10.21 & 18.5 & 16.69 & 15.5 & 12.5 \\
\hline $\mathrm{T}_{4}$ & 9.23 & 9.03 & 8.93 & 8.55 & 8.64 & 8.26 & 8.24 & 8.21 & 10.45 & 8.83 & 6.83 & 3.43 & 3.84 & 3.26 & 2.83 & 1.92 & 15.94 & 13.95 & 13.0 & 12.45 & 20.5 & 19.43 & 18.5 & 15.5 \\
\hline $\mathrm{T}_{5}$ & 9.40 & 9.12 & 9.05 & 8.72 & 8.89 & 8.34 & 8.29 & 8.24 & 13.05 & 11.93 & 8.94 & 4.02 & 4.64 & 4.08 & 3.91 & 2.78 & 18.93 & 16.44 & 15.0 & 13.81 & 22.0 & 19.31 & 19.5 & 16.25 \\
\hline $\mathrm{T}_{6}$ & 9.68 & 9.26 & 9.12 & 8.99 & 9.14 & 8.72 & 8.36 & 8.32 & 17.37 & 14.60 & 10.61 & 5.73 & 6.42 & 6.22 & 5.89 & 4.62 & 21.92 & 18.43 & 17.0 & 15.83 & 24.5 & 22.07 & 20.50 & 18.5 \\
\hline SEm \pm & 0.31 & 0.30 & 0.14 & 0.09 & 0.49 & 0.44 & 0.44 & 0.65 & 1.66 & 1.46 & 1.00 & 0.09 & 0.65 & 0.44 & 0.53 & 0.49 & 1.20 & 0.75 & 0.43 & 0.27 & 0.65 & 0.51 & 0.44 & 0.42 \\
\hline $\mathrm{CD} p=0.05)$ & 0.66 & 0.93 & 0.29 & 0.27 & 1.48 & 1.31 & 1.31 & 1.97 & 3.55 & 4.42 & 3.01 & 0.28 & 1.97 & 1.32 & 1.60 & 1.47 & 3.63 & 2.28 & 1.32 & 0.81 & 1.97 & 1.54 & 1.31 & 1.28 \\
\hline
\end{tabular}

Table.4 Effect of raw spentwash and gypsum application on $\mathrm{Na}$, chlorides and bicarbonates content of leachate collected from sodic and calcareous sodic soil.

\begin{tabular}{|c|c|c|c|c|c|c|c|c|c|c|c|c|c|c|c|c|c|c|c|c|c|c|c|c|}
\hline \multirow[t]{3}{*}{ Treatments } & \multicolumn{8}{|c|}{$\mathrm{Na}\left(\operatorname{meq} \mathbf{L}^{-1}\right)$} & \multicolumn{8}{|c|}{$\mathrm{Cl}^{-}\left(\operatorname{meq} \mathrm{L}^{-1}\right)$} & \multicolumn{8}{|c|}{$\mathrm{HCO}_{3}^{-}\left(\operatorname{meq} \mathrm{L}^{-1}\right)$} \\
\hline & \multicolumn{4}{|c|}{ Sodic } & \multicolumn{4}{|c|}{ Calcareous sodic } & \multicolumn{4}{|c|}{ Sodic } & \multicolumn{4}{|c|}{ Calcareous sodic } & \multicolumn{4}{|c|}{ Sodic } & \multicolumn{4}{|c|}{ Calcareous Sodic } \\
\hline & $\begin{array}{c}30 \\
\text { days }\end{array}$ & $\begin{array}{c}60 \\
\text { days }\end{array}$ & $\begin{array}{c}90 \\
\text { days }\end{array}$ & $\begin{array}{c}120 \\
\text { days }\end{array}$ & $\begin{array}{c}30 \\
\text { days }\end{array}$ & $\begin{array}{c}60 \\
\text { days }\end{array}$ & $\begin{array}{c}90 \\
\text { days }\end{array}$ & $\begin{array}{c}120 \\
\text { days }\end{array}$ & $\begin{array}{c}30 \\
\text { days }\end{array}$ & $\begin{array}{c}60 \\
\text { days }\end{array}$ & $\begin{array}{c}90 \\
\text { days }\end{array}$ & $\begin{array}{c}120 \\
\text { days }\end{array}$ & $\begin{array}{c}30 \\
\text { days }\end{array}$ & $\begin{array}{c}60 \\
\text { days }\end{array}$ & $\begin{array}{c}90 \\
\text { days }\end{array}$ & $\begin{array}{c}120 \\
\text { days }\end{array}$ & $\begin{array}{c}30 \\
\text { days }\end{array}$ & $\begin{array}{c}60 \\
\text { days }\end{array}$ & $\begin{array}{c}90 \\
\text { days }\end{array}$ & $\begin{array}{c}120 \\
\text { days }\end{array}$ & $\begin{array}{c}30 \\
\text { days }\end{array}$ & $\begin{array}{c}60 \\
\text { days }\end{array}$ & $\begin{array}{c}90 \\
\text { days }\end{array}$ & $\begin{array}{c}120 \\
\text { days }\end{array}$ \\
\hline $\mathrm{T}_{1}$ & 9.77 & 9.65 & 8.97 & 8.83 & 1.86 & 1.65 & 1.23 & 1.12 & 1.12 & 1.08 & 0.96 & 0.85 & 1.85 & 1.72 & 1.68 & 1.63 & 1.83 & 1.61 & 1.57 & 1.51 & 2.6 & 2.39 & 2.17 & 2.4 \\
\hline $\mathrm{T}_{2}$ & 9.92 & 9.80 & 9.22 & 8.87 & 2.56 & 2.14 & 1.96 & 1.84 & 1.24 & 1.16 & 1.05 & 0.93 & 2.12 & 2.06 & 1.96 & 1.85 & 2.00 & 1.85 & 1.66 & 1.61 & 3.1 & 2.79 & 2.23 & 2.5 \\
\hline $\mathrm{T}_{3}$ & 10.24 & 10.18 & 9.42 & 8.95 & 3.02 & 2.87 & 2.02 & 1.86 & 1.35 & 1.23 & 1.18 & 1.12 & 2.23 & 2.15 & 2.11 & 2.08 & 2.31 & 2.13 & 1.73 & 1.69 & 3.5 & 3.19 & 2.81 & 3.2 \\
\hline $\mathrm{T}_{4}$ & 14.73 & 12.40 & 10.12 & 9.42 & 6.56 & 5.78 & 2.65 & 1.38 & 2.52 & 1.86 & 1.52 & 1.43 & 3.85 & 3.62 & 3.35 & 3.06 & 6.32 & 5.80 & 5.03 & 4.96 & 5.6 & 5.32 & 4.83 & 4.52 \\
\hline $\mathrm{T}_{5}$ & 15.37 & 13.50 & 11.27 & 10.36 & 8.14 & 6.89 & 4.18 & 2.39 & 3.24 & 2.95 & 2.31 & 1.90 & 5.69 & 5.28 & 5.04 & 4.95 & 9.72 & 8.90 & 7.39 & 7.03 & 9.2 & 8.83 & 7.64 & 8.35 \\
\hline $\mathrm{T}_{6}$ & 18.14 & 14.77 & 12.50 & 11.22 & 10.25 & 7.36 & 5.21 & 3.96 & 4.13 & 3.72 & 3.09 & 3.24 & 6.12 & 5.83 & 5.46 & 5.21 & 11.64 & 10.61 & 9.85 & 9.63 & 10.8 & 9.24 & 8.91 & 9.89 \\
\hline $\mathrm{T}_{7}$ & 20.33 & 15.63 & 13.77 & 12.48 & 12.58 & 10.43 & 8.63 & 5.94 & 6.06 & 5.15 & 4.76 & 4.63 & 6.78 & 6.65 & 6.33 & 6.18 & 13.32 & 12.43 & 10.68 & 11.79 & 14.8 & 11.50 & 10.14 & 11.64 \\
\hline SEm \pm & 0.31 & 0.24 & 0.15 & 0.14 & 0.49 & 0.44 & 0.49 & 0.31 & 0.52 & 0.36 & 0.28 & 0.24 & 0.54 & 0.26 & 0.31 & 0.55 & 0.44 & 0.43 & 0.26 & 0.44 & 0.87 & 0.44 & 0.54 & 0.85 \\
\hline $\mathrm{CD} p=0.05)$ & 0.95 & 0.73 & 0.46 & 0.43 & 1.47 & 1.31 & 1.47 & 0.93 & 1.59 & 1.10 & 0.85 & 0.72 & 1.63 & 0.77 & 0.93 & 1.66 & 1.32 & 1.31 & 0.78 & 1.32 & 2.63 & 1.32 & 1.62 & 2.55 \\
\hline
\end{tabular}


Increasing quantities of raw spentwash application significantly increased the $\mathrm{pH}, \mathrm{EC}$, $\mathrm{HCO}_{3}{ }^{-}, \mathrm{Cl}^{-}, \mathrm{SO}_{4}{ }^{2-}, \mathrm{Ca}^{2+}, \mathrm{Mg}^{2+}$ and $\mathrm{Na}^{+}$, in leachate samples. Similar observations were made by Devarajan and Oblisami (1995) and Malathi (2002).In general, $\mathrm{pH}$ and EC of the leachate collected at different intervals increased which might be due to leaching of salts, which increased the $\mathrm{pH}$ of leachate.

Salt concentration in the leachate increased with increasing levels of raw spentwash. Application of raw spentwash @10.0 lakh liters $\mathrm{ha}^{-1}$ recorded significantly higher values compared to gypsum amended plots. Among the anions, $\mathrm{HCO}_{3}{ }^{-}>\mathrm{Cl}^{-}>\mathrm{SO}_{4}{ }^{2-}$ leached in higher quantities.

In general, anions concentration increased with greater quantity of raw spent wash application and it decreased with increase in different days after application. Among cations $\mathrm{Na}^{+}$leached was more compared to $\mathrm{Ca}^{2+}$ and $\mathrm{Mg}^{2+}$ as it is monovalent, retention on exchange site is less compared to $\mathrm{Ca}^{2+}$ and $\mathrm{Mg}^{2+}$ which are being divalent, get strongly adsorbed on clay surface.

A similar result of increased salt content in ground water near lagoon sites in most of the distilleries was noticed by Joshi et al., (1994). Husain et al., (2003), Anilkumar et al., (2003), Malathi (2002) and Suma (2006) who noticed the leaching of anions and cations from soil profile with higher quantities of spentwash. Concentration of these cations and anions in the leachate decreased gradually upto 120 days after application.

\section{References}

Anil Kumar, Yashpal Singh, Joshi, B. D. and rai, J. P. N., 2003, Effect of distillery spent wash on some characteristics of soil and water. Indian J. Eco., 30: 712.
Anonymous, 2002, Eco-friendly utilization of distillery spentwash for improving Agriculture productivity in dryland and high $\mathrm{pH}$ soils of Theni District. Scheme sponsored by Rajshree sugars and Chemicals Ltd., Department of Environmental Sciences Tamilnadu Agricultural University, Coimbatore.

Anonymous, 2005, Annual Report, Research and Development committee, Karnataka Brewers and Distillers Association, Bangalore.

Baskar, M., Kayalvizhi, C. and Subash Chandra Bose, M., 2003, Eco Friendly utilization of Distillery Effluent in Agriculture- A Review. Agric. Rev., 24:16-30.

Chauhan, C. P. S. and Tripathi, B. R., 1983, Reclamation studies on highly saline sodic soil of semi-arid tract in UP. $J$. Indian Soc. Soil Sci., 31:587-595.

Devarajan, L. and Oblisamy, G., 1994, Performance of banana (Poovan), under distillery effluent irrigation. South Indian Horticulture, 42: 324326.

Joshi, H. C., Kaira, N., Chaudhary, A. and Deb, D. L., 1994, Environmental issues related with use of distillery effluents in agriculture in India. Asia Pacific J. Environ. Devlop., 1(2): 92103.

Guruprasd, M. S, 2005, Characterization and Reclamation of sodic soils in Kabini Tract of Cauvery command area, M.Sc Thesis submitted to UAS, Bangalore.

Hussain, Galjaloud and Karimullas, 2003, Effect of treated effluent irrigation and $\mathrm{N}$ on yield and $\mathrm{N}$ use efficiency of wheat. Agric. Water Management, 30(2): 175-184.

Mahendra, A. C, 2007, Studies on reclamation of sodic soil through distillery spentwash, M.Sc. (Agri) Thesis, submitted to UAS, Bangalore.

Malathi, M. P., 2002, An assessment of 
distillery spentwash for its possible pollution potential in dry land areas. M.Sc. Thesis, Tamilnadu Agricultural University, Coimbatore, India.

Mohamed Haroon, A.R., and Subash Chandra Bose, M., 2004, Use of distillery spent wash for alkali soil reclamation, treated distillery effluent for fertigation of crops. Indian farming, March: 4851.

Patil, G.D., Pingat, S. M. and Yelwande, A. J., 2000, Effect of spentwash levels on soil fertility, uptake, quality and yield of Fodder Maize. Journal of Maharashtra Agric. Univ., 25: 168170.

Rachhpal Singh, Singh, N. T. and Yogesh Arora, 1980, The use of spentwash for the reclamation of sodic soils. J. Indian Soc. Soil Sci., 28(1): 38-41.

Rajakannu, K., Manickam, T. S., Shanmugam, K., Chandrasekaran, A. and Gladis, R., 1996, Distillery spentwash development of technology for using it as an amendment for reclamation of sodic soils. In: Proceedings of National Symposium on use of distillery and Sugar industry wastes in Agriculture, held at ADAS \& RI, Tiruchirapalli on $28^{\text {th }}$ and $29^{\text {th }}$ October, pp. 30-39.

Ramappa Jakanur, 1998, Evaluation of flyash as an amendment for reclamation of sodic soils. M.Sc. Thesis, University of Agricultural Sciences, Dharwad.

Santiago Mahimairaja and Nanthi, S., Bolan, 2000, Analysis and recommendation of agriculture use of distillery spentwash in Rampur district, India. Third Australian New Zealand Soils Conference. 5-9 December 2000. University of Sidney, Australia.

Srinivasa, N., 1995, Characterization and Reclamation of sodic soils in Vishveshwaraih Canal Tract of Cauvery command area, PhD Thesis submitted to UAS, Bangalore.

Suma, R., 2006, Ferti-irrigation studies with distillery spentwash on sugarcane under southern dry zone of Karnataka, Ph. D Thesis submitted to UAS, Bangalore.

Susheel kumar sindhu, amit shrama. and Saiqa Ikram, 2007, Analysis and Recommendations of Agriculture use of Distillery spentwash in Rampur District, India. J, Chem., 4(3): 390396.

Valliappan, K., 1998, Recycling of distillery spentwash and eco-friendly effective reclamation technology for soils. Ph.D. Thesis, Tamilnadu Agricultural University, Coimbatore, India.

\section{How to cite this article:}

Bhagya Lakshmi, T., C. A. Srinivasamurthy, H. R. Savitha, D. H. Roopashree and Bhaskar, S. 2019. Distillery Raw Spent Wash as an Amendment for Reclamation of Sodic and Calcareous Sodic Soil. Int.J.Curr.Microbiol.App.Sci. 8(10): 781-794. doi: https://doi.org/10.20546/ijcmas.2019.810.090 